\title{
Shooting the fox? UKIP's populism in the post-Brexit era
}

Simon Usherwood (s.usherwood@surrey.ac.uk)

\begin{abstract}
The UK Independence Party (UKIP) has moved from being a single issue party par excellence to a broader party of protest, taking advantage of broader feelings of discontent and disconnection. However, the 2016 referendum on UK membership of the EU fundamentally challenged its development and operation, by removing a core part of the party's rationale and identity, and radically shifting the overall political landscape. This paper considers the repositioning through the referendum period, both rhetorically and organisationally. Drawing on party press releases and media coverage, the paper argues that UKIP has become caught in a set of multiple transformations, pushing it in the longer term towards a more conventionally populist position, in a way that carries important resonances for other eurosceptic parties across the continent.
\end{abstract}

Keywords UK Independence Party; Brexit; Populism; Single-issue politics; Leadership 


\section{Introduction}

One of the defining features of European populism is the wide variety of manifestations found across national systems. This variety moreover cuts across ideological lines, but also programmatic priorities and development over time. While it is right to search for underlying commonalities in this diversity (e.g. Mair 2013; Hernandez and Kriesi 2015; Mudde and Kaltwasser 2011), it also remains important to recognise that particularities also remain and have an impact (Gidron and Bonikowski 2013; Caiani and Graziano 2016). This paper considers precisely this impact, by considering the case of the UK Independence Party (UKIP) in the wake of the June 2016 UK referendum on membership of the European Union (EU).

Furthermore, one of the recurring features of populism is its adaptability (see Taggart 2000; Mèny and Surel 2002), casting and re-casting its core elements - of 'the people' against pernicious 'elites' (Albertazzi and McDonnell 2007) - to suit very different situations. Importantly, this is not only an adaption to different national situations, but also to different situations over time within national contexts: populist parties are incomplete and temporary manifestations of underlying structural developments in politics and society. The opportunity structures that present themselves in any national system will change over time, usually gradually but occasionally radically, in part through the actions of the political actors involved (Kitschelt 1986). So it is with UKIP and the radical upheaval of British politics that has come with the decision on Brexit. The party was built on a foundation of a single-issue as seen in with other European populist parties (Ivarsflaten 2008) - of opposition to European integration, and this has been the policy it is most associated with in the public's mind, notwithstanding the growth in importance of a more conventionally exclusionary policy on immigration: With the referendum validating the original policy and securing its core demand, the question that immediately rises for the party is one of whether it has any 
continuing purpose. UKIP has been successful in mobilising and representing a broad coalition of supporters in the years running up to the referendum for reasons that extended well beyond the European issue (Ford and Goodwin 2014), but it now has to adapt to the apparent removal of that core of its work. As this special issue invites reflection on the changes wrought in Europe in recent years on populism, the central research question is whether Brexit has made UKIP into a more conventionally exclusionary European populist party? This natural experiment thus offers an instructive counterpoint to the disruptive processes found in other European countries (e.g. Lisi et al 2018).

To answer this question, the article proceeds as follows. Firstly, it considers the particularities of UKIP as a populist party and the extent to which the factors of its origin, programme and ideology might shape its response to the changed realities of the Brexit era. The core argument that will be made is that while the party might have identified the issue of relevance, it finds itself in a changed situation, both because of its reduced internal capacity and because of a less sympathetic external environment. That external environment is not only shaped by the 2016 referendum, but also by the changing constellation of British party politics, and the changing policy of the Conservative party in particular (Bale 2018). Through analysis of party press releases, newspaper coverage and public opinion data over the period between February 2015 and October 2017, the paper will discuss how these different data sources shine light on the dilemmas faced by UKIP and the choices taken by it. While those choices might seem to be bringing UKIP more in line with the forms of populism found in other European states (Mudde and Kaltwasser 2012) it is also evident that the size and the difficulty of the transition will be very substantial, and with no guarantee of success. 


\section{UKIP as an outlier}

As much as UKIP is often rolled in with other European populist parties making advances in recent years (e.g. Rooduijn and Puwels 2011; Halikiopoulou and Vasilopoulou 2014; Akkerman et al 2016), the party has a very distinctive origin, path of development and ideological disposition. While it is undoubtedly a populist party (Hayton 2010; Usherwood 2016; Taggart 2018), it has grown into that definition, from its roots as a single-issue party.

At its foundation in the early 1990s, the party was built as a purely single-issue organisation: to precipitate the UK's withdrawal from the then-new European Union. Its founder, Alan Sked, a professor at the London School of Economics, proposed that UKIP would contest seats in the European Parliament and then refuse to take them up, so as to cause a constitutional crisis. The roundabout policy not only belied its academic roots, but also the constellation of individuals that the party had drawn together: not only disillusioned Conservatives, mobilised by Margaret Thatcher's Bruges speech of 1988, but also those from other parties (and none) who saw European integration running far beyond the market-led approach of the 1980s (Spiering 2004). The fragility of this coalition was very evident throughout the 1990s, with repeated internal splits, a constant need to rebuff entryist efforts from the far-right and a major challenge in 1997 from the Referendum Party (Daniel 2005). The collapse of the latter left an enlarged constituency for UKIP, which it was able to capitalise on with the change in electoral system for the 1999 European elections. The foothold that its 3 MEPs - now following a policy of taking their seats - were able to create, together with the funding associated with their election, was to be critical in sustaining the party through its juvenile phase.

As much as European issues were important in British politics at this time - most obviously with the long debate about British membership of the Euro - UKIP was only able to secure representation at the European level: both national and local elections produced no 
successes at this stage. Indeed, it is striking that it was only at the point that the party began to broaden its message from the single issue of 'Europe' - and thus become more conventionally exclusionary - that there was a growth in both in public profile and its electoral success. The 2004 European elections proved a major break-through, with a combination of high-profile candidates, a strong campaign theme based on anti-establishment ideas and the disarray of opponents resulting in 12 MEPs (Butler and Westlake 2005). Each subsequent cycle of European elections saw further growth in both vote share and representation (Usherwood 2016).

This electoral success was paralleled by the development of an ever wider set of policies, among which controls on immigration was the most important. This tessellated neatly with the continuing core EU message, as UKIP made much use of its withdrawalist position on the latter to highlight how other parties were unwilling and unable to impose limits on intra-EU migration (as freedom of movement has typically been framed in the UK): thus the original core became interwoven with ever more additions. The gradual emergence of local branches of the party in the 2000s also permitted the development of a Liberal Democrat-style localism and a reinforcement of the party's profile as a destination for protest votes (Tournier-Sol 2015), with local representatives able to speak more credibly about those issues too trivial for the national stage. That credibility helped to lay the groundwork for the sustained efforts to secure national representation, with the defection of two Conservative MPs in late 2014. Notwithstanding that it later became apparent that their defection was part of a larger gambit by eurosceptic elements in the Conservatives to 'detoxify' UKIP prior to any EU referendum (Shipman 2016 has the best account of this), the image conveyed to both public and politicians was that UKIP was on the brink of becoming part of the mainstream, as the Tories continued their inner turmoil over 'Europe'. 
Beyond this organisational and programmatic development, it is also important to stress the more general evolution of the party to a more pragmatic - and indeed populist - position. This is evident in a number of areas, most importantly in its conceptualisation and articulation of its policy towards the EU, its core project. The movement from non-engagement on principle, to pragmatic but very limited engagement, and then to the reframing of the EU within a bigger project of anti-establishmentarianism reflects the changing base of UKIP; something that predates the step-change in the party's profile (as seen in Gardner 2006 and Usherwood 2008). Whereas once the party conceived of itself as having the sole purpose of triggering a crisis over the UK's membership of the EU, now it sees that as simply one step towards a UKIP government and a programme of policy. Such a shift is only possible because of the fundamental lack of a party ideology, as usually understood: the party does not like the European Union - just as it does not like uncontrolled immigration - but that dislike is not grounded in a single critique, nor less does it point to an ideologically-driven alternative policy: populism here is very much a matter of style and strategy, rather than on ideology (Gidron and Bonikowski 2013).

The ideological incoherence is an important part of understanding the party, for while the same can be said of other European populist parties, UKIP arrived at its situation from a particularly ideologically-wide starting point. While the policy focus was extremely limited literally a single policy on a single issue - this allow the party to get support from individuals from across the political spectrum: Sked was previously a Liberal activist and the leadership group has always included those from different backgrounds, even as former Conservatives have remained the most common source of members (Gardner 2006, YouGov 2016). That breadth was also supported by the strong efforts to resist far-right entryism - often at the cost of internal ruptures and removal of staff - allowing the party to argue with some more credibility about being within the boundaries of polite political debate (the more overt far-right 
having consistently struggled to achieve such acceptability in the UK (Goodwin 2007)). Through to the present, UKIP remains a collection of ideologies under the language of populism, rather than a cohesive ideological project. Here it is possible to contrast the libertarianism of Farage with the Tory politics of many other senior figures (Bale 2018), not to mention the old Labour politics of many recent followers of the party. As Wallace (2014) helpfully describes it, the party contains distinct 'tribes', each pulling the party in somewhat different directions, held together more by obfuscation and the politics of opposition than by any unifying positively-framed agenda. The party has thus always worked on the basis of solving problems on a 'common sense' basis, rather than achieving core values.

If the origins and the ideological vacuum of the party mark it out from counterparts elsewhere, then this has diminished over time. Most obviously, UKIP has moved on from its starting point and does now offer a full portfolio of policy positions and preferences and has articulated an inclusive rhetorical approach, grounded in classic populist tropes of common sense and external threat. For all that the party has fought hard - and repeatedly (Tournier-Sol 2015 ) - to resist entryism from far-right elements, the degree of overlap in its core policies on European integration and on immigration with radical right parties is very significant. While Mudde (2017: 7) is right to point out that it is not a populist radical right party, UKIP does still display many points of commonality, not least in its degree of personalisation on Nigel Farage.

Farage's involvement with UKIP stretches back to its foundation, but until 2006, when he became party leader, he had initially taken a back-seat role. With his move into the leadership, as already noted, he instigated a shift in policy and presentation, while simultaneously building up an inner-circle of supporters and advisers (Abedi amd Lundberg 2008; Usherwood 2016): potential successors or challengers were repeatedly marginalised or constrained, allowing Farage to remain pre-eminent. The brief interlude during the 2010 General Election campaign, when Lord Pearson struggled with both the media and the party, 
only served to underline Farage's value. As a highly charismatic individual (Crines and Heppell 2017), he was able to build a very significant media (and popular) following, as well as to overcome the ideological fissures that exist in the membership. In so doing, he has followed a path well-trodden by the Le Pens, Geert Wilders, Jörg Haider and many others in collapsing voters' conceptions of leader and party (see Taggart 1995; Weyland 2001). Naturally, such personalisation comes with costs, as Bynander and t Hardt (2006) point out: they undermine the longer-term health of the party and run the risk of charismatic effects becoming less effective at some future point, for reasons beyond the control of the individual.

What does all of this suggest for UKIP's post-referendum path and the degree to which it can be understood in terms of exclusionary populism? The impact can be most usefully divided into internal and external dimensions. Among the former - under the direct control of the party - the referendum might be expected to have had two distinct effects on its programmatic outputs. Prior to the referendum, the shift in public attention towards UKIP's core policy interest might be expected to result in more focus by the party on that issue: the party held a comparative advantage, as the only national party with an unambiguous and central policy commitment to withdrawal from the EU. However, after the vote, we would expect that attention would shift away from the EU issue, both because it would no longer hold its comparative advantage (as other parties adopted the referendum outcome as policy) and as the party sought to establish its continuing relevance to public debate beyond what would now become a time-limited issue Overall, the referendum is therefore expected to result in a party that focus even more on those aspects that speak to conventional exclusionary populism, as it seeks to move beyond its original purpose.

By contrast, the anticipated pattern of external factors will present a different picture. Media coverage of the party would be expected to follow the party's lead, with an increasing focus on the EU issue in the run-up to the referendum, but thereafter we would not anticipate 
a similar re-focusing to other issues. This is based on Hopmann et al. (2010) model, which suggests that relevant parties are more successful in influencing media coverage, coupled to a perceived weakening of party relevance (in the broader sense) post-referendum. This will also be reflected in a change in public opinion, with a sustained drop in support for UKIP post-referendum.

Finally, we expect that the 'Farage effect' will persist post-referendum. This includes both internal and external elements. The party has its strongest media and public asset in Farage, and so has a clear interest in maintaining its links to him and his name. Likewise, in the absence of any other party figure of remotely comparable stature, the media will continue to make the connection between Farage and UKIP.

\section{Methodology and data}

To test these expectations, we make use of two novel data sets. To explore internal aspects of the party, we have compiled a set of all press releases produced by the party between late February 2015 and the election of Henry Bolton as party leader in October 2017, and stored on the party's website. These press releases represent the most uniform source of output by UKIP in this period, with a process of central coordination and approval in their production and dissemination: the decision to produce a release does not sit with individual policy spokesmen. Moreover, by this same token, we can assume a minimum level of central interest in a release to warrant its authorisation and distribution (as in Norris 2003).

Comprising 1219 releases, the data is coded for content on key words. The time period covers the run-up to the 2015 general election, the entire EU referendum period and the immediate subsequent reorganisation of the party. 
The second source of data is that of articles from the Daily Express for the same period. As Startin (2015; see also Deacon and Wring 2016) notes, the Express has become very closely aligned with UKIP since 2010, when it launched a campaign to promote UK withdrawal from the EU. Since then, there has been movement of personnel - most notably the political editor, Patrick O'Flynn, becoming a UKIP MEP in 2014 - and financial backing by the paper's owner, Richard Desmond, to the party, to the point that it can be considered the 'house journal' of the party during the period under consideration. The closeness of that relationship offers a good opportunity to test the expectations on external profile, since this is the most sympathetic outlet available to UKIP and thus the one best-placed to test Hopmann et al. (2010) arguments. Articles were taken from the Nexis database, on a search for 'UKIP', with cleaning for duplicates and non-UK editions, before being coded in the same fashion as the press releases.

\section{Analysis}

The period between 2015 and 2017 was a critical one for UKIP. At the start of the survey period, the party was working on the assumption that it was on the verge of breaking through into significant representation in the House of Commons, as support for both Conservatives and Labour parties fell and as UKIP appeared to be attracting defectors from both at an increasing rate. The working assumption was that there was political space to sell a message about a new formulation of politics at a time when the two main parties in Westminster looked set for deadlock and coalition talks (Bale 2018; Webb and Bale 2014; Gruber and Bale 2014; Mellon and Evans 2015). However, the unexpected victory of the Conservatives in May 2015 opened up a completely different set of opportunities. Not only was a referendum on EU membership now in place, but Labour seemed to be set on a more 
radical course under Jeremy Corbyn, potentially opening the doors to more aggressive campaigning in old Labour heartlands by UKIP. That potential remained in the wake of the referendum itself, when UKIP was looking to establish its continued relevance. The final twist came with the snap general election in June 2017, which saw the wholesale adoption by the Tories of UKIP's central programme (see Heath and Goodwin 2017; Tilley and Evans 2017), cemented Corbyn as a credible and electorally-attractive leader and left UKIP with an incomplete and uncertain position. Party instability continued beyond the survey period into 2018 with the brief and troubled leadership of Bolton, so care has to be taken not to overinterpret practice during this time, but taken together, there are still four distinct phases to the analysis of the data, each marked by an unexpected turn of events: Table 1 and Figures 1-4 summarise the key findings from the press releases and newspaper articles.

TABLE 1 AND FIGURES $1,2,3$ \& 4 ABOUT HERE

In the first phase, prior to the May 2015 general election, UKIP appeared to be following a strategy of balancing their core interests in the EU and immigration with output focusing on other topics. Most over half of the press releases in this period made no mention at all of either the EU or immigration, instead covering subjects as varied as transport, defence, health and the economy. Those subjects typify UKIP's stylist populism, framing them in prosaic terms of ending car-park charges at hospitals, or building low-cost housing. When immigration was mentioned, in almost 2 in 3 cases so too was the EU, reflecting a long-run strategy of connecting the two subjects (Ford and Goodwin 2014). This was also the period during the survey timeframe that saw the most frequent mention of the leader's name, 
with Farage appearing in over $40 \%$ of releases, leveraging his high name-recognition and brand of political authenticity (Bossetta 2017) to reach voters. Similarly, this was also the period that had the most frequent references to Labour and the Conservatives, always in negative terms, contrasting the common-sense, populist approach of UKIP to the failed 'mainstream'. Coverage by the Express largely reflects this overall approach, with a very similar pattern of coverage.

However, following the 2015 general election, there is a marked shift in approach, with an increasing focus on EU-related topics in the run-up to June 2016. Almost $60 \%$ of press releases mention the EU in this period (and over $75 \%$ in May 2016), while the connection with immigration is strongly reinforced, with over $80 \%$ releases mentioning the latter also referencing the former. This pattern of topics is also matched in Express articles. There are also far fewer references to the Conservatives or Labour in the period, reflecting the nature of the referendum debate, cutting across party lines. While both press releases and articles make less reference to Farage than before May 2015, the shift is much more marked in the former: The Express still manages to mention Farage in nearly every other article over the period.

If the run-up to the referendum saw a swing back to the original core interest of UKIP, then the period after saw the opposite. Reference to the EU in press releases drops steeply, while immigration references also become fewer in number: in the period to June 2017 , almost $60 \%$ of releases mention neither of these topics. Instead, the focus shifts back to the wider range seen prior to the 2015 general election: the party produces a mixture of responses to issues of public interest and a number of policy documents, intended to claim more of the political ground. A key moment came in February 2017, when the new party leader, Paul Nuttall, announced his intention to prepare 'detailed and costed policies' to frame UKIP as 'the patriotic party that advances common-sense solutions to many of the problems that are holding [the British people] back in their lives' (UKIP 2017). Nuttall himself clearly used the 
press releases to mark himself out as a new figurehead for the party, appearing in over a third of those issued during his leadership, with only very occasional mentions of Farage (and these mainly relate to his continuing position as an MEP). But on this last point there is a divergence with the Express, which while keen to name-check Nuttall at levels seen under Farage, it also continued to mention Farage himself even more frequently: a recurring theme of the entire period following the referendum was the publication of editorials and readers' letters calling for his return as party leader, as the only individual capable of guiding the party and country through the Brexit process. This ties in with the continued focus on EU-related subjects by the Express at this time, with over half of all articles mentioning this, even as the party tried to broaden its agenda.

This divergence became even more marked immediately after the 2017 general election, when the Express largely stopped name-checking the interim leader, Steve Crowther, even as it continued with frequent references to Farage (see Figure 3). Indeed, it is also striking that the volume of articles also shrinks at this time, to under half the level previously observed. References to the EU and to immigration remain more common in the newspaper than the press releases, even as the party reverted to much more frequent discussion of both. In large part this shift back to the EU was an amplification of the postreferendum phase, inasmuch as the party has made increasingly frequent pronouncements on the need to pursue withdrawal from the EU in a timely and decisive manner, railing against those who might seek to frustrate that objective. This was also marked by an increasing number of references to the Conservatives and Labour in the press releases.

FIGURES 5 \& 6 ABOUT HERE 
Against the backdrop of these shifts in party profiling, it is also useful to consider the changing public support for the party (see Figure 5). As before, this appears to follow a set of changes that broadly coincides with the periods already outlined. The run-up to the 2015 general election saw consistent polling in the high teens, followed by a fall back towards $10 \%$ immediately after. However, support returned to its previous highs as the referendum drew closer, before falling back to the low teens through the rest of 2016 and early 2017 . The short campaign in 2017 for the general election was marked by a large drop in support (mirroring the rise in Labour support), settling post-vote at around 5\%. However, this mirroring was not the result of direct defections from UKIP to Labour, but rather of UKIP's voter base splitting: preliminary data from the British Electoral Survey (2017; see also Dennison 2018) suggests one-third went to the Conservatives - less than the latter might have expected - plus a substantial volume of non-voting. Labour picked up many more votes from former Tories and floating voters than from former UKIPers.

Previous analyses have highlighted the extent to which UKIP has drawn voters from across the political spectrum, including many previously non-voters or lapsed voters (e.g. Cowley and Kavanagh 2016; Cutts et al. 2017): similarly, the 2017 vote has seen this flow in reverse (Heath and Goodwin 2017), with UKIP voters heading as much to Labour as to the Conservatives. Taken in aggregate, it appears to be in periods when support for those two parties taken together is low that UKIP has prospered electorally, especially in the period since the mid-2000s, in line with Ford and Goodwin's (2014) argument that the party had carved out a niche as a vehicle to represent the 'left behinds'; those who had not benefited from social and economic change in recent decades. However, the data for the period under consideration does raise a question about how much this still holds true. In particular, the shift at the 2017 general election appears to have undercut the claim to electoral relevance that the party was making post-referendum. Having held on too much of its polling share in 
the year after the referendum, under new leadership and with a more diversified portfolio of policies and priorities, the loss of over half of that support from June 2017 points to a potential collapsing of the particular situation that emerged from 2010, where UKIP could play a particular populist role as an outsider group.

This is further underlined by the evidence presented in Figure 6, which plots the percentage of the British public who consider either the EU or immigration as an important issue (drawing on the long-running Ipsos-Mori 2017 datset). The former has consistently run below $10 \%$ for the entire period since the early 2000s, and was part of UKIP's decision to diversify its policy (Gardner 2006): relatively few people still felt that European integration was a matter of much concern, fewer still a reason to change voting allegiances. The rise of concern about immigration, especially in the wake of the EU's 2004 enlargement to Central and Eastern Europe (see Boomgaarden et al. 2011; De Vreese and Boomgaarden 2005), provided a new opportunity for UKIP to extend its policy platform in an organic extension of its position on the EU. While that concern appears to have fallen back since the 2016 referendum, it has been offset by the strong rise in interest in the EU as an issue, as the process of withdrawal moves towards its conclusion. However, neither issue has a significant correlation with vote share over this period.

This leads us back to the expectations set out above, since they point to the elements of that situation and the question of whether it still applies. Certainly, the 2016 referendum does appear to have increased the incentives for the party to renew its focus on the EU. Press releases prior to May 2015 showed a high degree of diversification away from this topic, in line with the party's efforts to recast themselves as a more conventionally (in European terms) exclusionary populist party, but this shifts demonstrably in the run-up to June 2016, with ever-increasing direction of positions towards the European issue. Moreover, this then falls away after the vote, as UKIP tried to return to its pre-May 2015 situation under new 
leadership. However, the period since June 2017, following the general election and the resignation of Paul Nuttall, does call into question how robust a relationship there is. On the one hand, public interest in the EU is rapidly increasing and output has become more EUfocused again, but on the other this has not translated back into public support, which has fallen in this period, especially post-2017, which suggests that the previous transmission belt of UKIP supply feeding into public demand no longer works as it used to, not least because of the co-option by the Conservatives of the party's key agenda points.

The failure of transmission is also seen in media coverage. While the Express coverage did track UKIP output through to the referendum, there is a much smaller shift back to nonEU-related coverage post-referendum, alongside a sharp fall in the volume on coverage post2017 general election. This might be best understood when considering the continued interest by the Express in Nigel Farage, who remained much more present in their coverage than was the case for the party itself as much as the party has sought to build a new image of itself away from the profile of their former leader, he still provides a highly mediatisable figure and one whose links with journalists make him a convenient pathway. This might also explain the rise of Express content that talks of internal UKIP disputes, which was absent during Farage's leadership, just as it explains the appearance of Farage in the sports section, attending tennis matches.

\section{Discussion and conclusions}

It is important not to overstate the particularity of UKIP: As much as its genesis and development have followed a very particular path, it shares much in common in its more mature form with other populist parties, even as it retains an unusual preoccupation with European integration. This 'single issue populism', as it might be termed, is of wider interest, 
because it exposes in a more visible way how a particular policy line can impact a party's approach across the board. Moreover, it offers an insight into how much a party can uncouple itself from its past, both in its self-image and in how others portray it.

UKIP's particular situation has often worked in its favour. The narrow focus on European integration allowed it both to avoid marginalisation as 'another far-right party', while also giving a degree of policy space not available to its competitors in the party political system. As UKIP developed into a more broadly-based organisation in the 2000s, it was able to take that unique mix as the basis for establishing a much broader coalition, grounded in conventionally exclusionary populist rhetoric and lead by a charismatic individual: the party became a berth for those who felt that the system was not working for them or their interests, tapping into the secular rise in distrust found across democracies (Ford and Goodwin 2014). That balancing act - offering very ideologically diverse policies, dressed in the language of change and 'independence' (Gardner 2006) - was facilitated by a Conservative party that simultaneously left policy space open and normalised more radical policy on European integration (Bale 2018), and brought the party to third place in the 2015 general election, with $12.6 \%$ of the vote, the best performance by a fourth party in the post-1945 period. However, that success has been more brittle than it might have appeared in 2015. The promise - ultimately carried through - to hold a referendum on British membership of the EU has ultimately collapsed this particular constellation of success. This is due to three, interlinked elements. The first has been the changing nature of UKIP itself. Having already sought pre-2015 to diversify its base, the party had tried to transcend its origins: few people felt European integration was a priority of public policy, while immigration was an area of growing concern (and one where UKIP could offer more radical solutions than other parties). The pre-eminence of Nigel Farage gave the party an internal coherence that allowed it to make this change while still presenting a united public face that could be underpinned by the 
likely long-term failure of the other parties to offer any credible opportunity to challenge the UK's membership of the EU: they might talk tough on Europe, but only UKIP was prepared to commit unambiguously to leaving.

David Cameron's unexpected re-election in 2015 called that bluff and exposed a strategic blind spot in UKIP's model: either it would lose a referendum, and thus take the matter out of public debate for many years, or it would win, and then have its purpose called into question. UKIP was certainly alive to this dilemma, but the opportunity to secure its core objective was impossible to ignore and it tried to rebalance itself during 2015-6 to make the most of its particular position in the public debate to maximise the Leave vote. Tellingly, that did not mean a wholesale dropping of its other policies, but rather an active involvement in the unofficial, but still very substantial Leave.EU campaign group (Shipman 2016; Banks 2016): just as other parties sought to preserve some independence during the campaign by contributing to cross-party groups, so too did UKIP, while still running a portfolio of other, non-EU activities alongside.

While that work did contribute to the eventual success of Leave (Farrell and Goldsmith 2017), it both robbed the party of its central policy platform and of its leader. Farage's departure was always going to be problematic for a party structure that had come to rely on him personally to quite such a degree, as was seen in the 2015 'un-resignation' when he was dragged back to the role of leader almost as soon as he handed in his notice. The degree of media comment - and discontent within the party - around this made it hard to repeat that process in June 2016, but it seems that Farage had, in any case, decided that then would be the best moment to leave, at the point of the vindication of his political career to date. While this might have been good for Farage, it was less obviously so for the party, which now had to navigate a very different situation with a new leader and a necessarily different policy focus. 
These internal changes to the party also came at a time when the media environment was changing. As the data from the Express - the party's semi-official media partner - highlight, the narrative that the party wanted to communicate was not necessarily the one that the media wanted to convey. The personalisation of coverage in Farage, and the priority given to the party's anti-EU message left much less space in which to make the manoeuvre that the party was attempting. This raises a question of the motivation for the Express's support: was it driven by a general attachment to the party's policy programme, to its anti-EU stance, or to the person of Farage himself? As Startin (2015) rightly points out, the paper has taken a very strong line on the EU and on immigration, often having no-one but UKIP to provide supportive quotes. At the very least, the paper and the party used each other in support of their respective agendas, but those now appear to be diverging, especially with Desmond's February 2018 decision to sell the Express to Trinity Mirror.

This leads to the final element of the changing constellation for UKIP. The outcome of the referendum has meant that several of the mainstays of British politics have been upended. Not only is the UK now committed to extricating itself from an organisation that has been a central vehicle for public policy for several decades (see Evans and Menon 2017), but the relationship between direct democracy and parliamentary sovereignty is also challenged (Armstrong 2017). More particularly, the referendum has forced most political parties - most notably the Conservatives (Bale 2018) - to adopt a position on EU membership that largely matches UKIP's: to be out, but with a positive and constructive - if distant - relationship, or as Farage repeatedly stressed during the referendum "we are leaving the EU, not Europe." This closing down of the policy space represents a critical threat to UKIP, since it was central to its policy not only on European integration, but also on immigration. Any attempt to carve out a new, distinctive policy in either area is compromised both by the lack of obvious differentiators and by the spread of views within other parties: calls for a full and complete 
break with the EU are as common in the Conservative party as they are in UKIP, with the former having the additional weight of coming from the party of government.

The very strong re-assertion of the two-party system in the 2017 general election might seem to go against the party de-alignment hypothesis (Heath and Goodwin 2017), but a more careful reading is required here. The profound uncertainty over the UK's future path post-EU provided a strong incentive for voters to return to the security of trusted political parties. At the same time, neither the Conservatives nor Labour articulated a clear plan of how they would pursue that future (see Evans and Menon 2017; McKibben 2017). Given that this remains the case, even as the UK has moved into the formal Article 50 negotiations, this suggests there is a space in the political system for a challenge from populists of style and of ideology. As Jennings and Stoker (2017) note, there is evidence to suggest a continuing realignment of the British polity to a cleavage around cosmopolitanism, where a case could be made to those 'left-behind' about the value of a bigger populist project of nationalism and introversion. Put differently, the nearly-4 million votes secured by UKIP in 2015 did not disappear two years later because discontents had been satisfied, but because opportunity structure had shifted for voters: in an uncertain era, anyone might be able to deliver radical changes. For UKIP, that offers a window to rebuild their internal organisation, their media profile and their voter support. At the same time, it leaves the door open for other groups to fill that space and so is as much a threat as an opportunity: even if UKIP itself is not successful in making this transition, another populist grouping might well be.

The dynamics of the party-political system and the exigencies of Brexit would seem to be pushing UKIP towards an ever-more conventional conceptualisation and articulation of its populism, notwithstanding the reversion in EU-centred press releases in the immediate post- 
2017 General Election period. Rallying support to a single-issue banner of leaving the EU is no longer a tenable position, given the political position of the UK since 23 June 2016. Moreover, that banner cannot be easily replaced by an equally broad one of building a coalition for any one model of post-membership: that implies a necessary shift from a negative to a more positive core rhetoric, which in turn points towards more language of protest, especially given the accumulated weight of other policies on immigration and antiestablishmentism. In this, UKIP represents an important marker for other eurosceptic parties (see Taggart 2018) that might find that they also will have structural consequences that flow back from their position on European integration. Indeed, the British example is instructive for illustrating how European Union-level politics can have fundamental consequences for national political activity. Even if other countries do not follow the same path of withdrawal taken by the UK, the progressive increase in the range and depth of European policy over time means that positions on European integration are likely to become ever more salient. The Long Crisis has provided fertile ground for populists to strengthen the profile of their euroscepticism as a vehicle for their broader projects. However, as UKIP have amply demonstrated, the potential to become transformed by one's European policy is a clear possibility. Populists both shape and are shaped by their environments, potentially even more than other political parties.

\section{Disclosure statement}

No potential conflict of interest was reported by the authors.

\section{Notes on contributors}

Simon Usherwood is Reader in Politics at the University of Surrey. He studies euroscepticism and UK-EU relations and is Deputy Director of the ESRC's "UK in a Changing Europe”programme. [s.usherwood@surrey.ac.uk] 


\section{References}

Abedi, Amir, and Thomas Lundberg (2008). 'Doomed to failure? UKIP and the organisational challenges facing right-wing populist anti-political establishment parties', Parliamentary Affairs, 62:1, 72-87.

Akkerman, Tijtske, de Lange, Sarah, and Matthijs Rooduijn (eds.) (2016). Radical right-wing populist parties in Western Europe: into the mainstream?. London: Routledge.

Albertazzi, Daniele, and Duncan McDonnell (eds.). (2007). Twenty-first century populism: The spectre of Western European democracy. Basingstoke: Palgrave.

Armstrong, Kenneth (2017). Brexit Time: Leaving the EU-Why, How and When?. Cambridge: Cambridge University Press.

Bale, Tim (2018). 'Who leads and who follows? The symbiotic relationship between UKIP and the Conservatives-and populism and Euroscepticism'. Politics, 38:3, 263-277.

Banks, Arron (2016). The Bad Boys of Brexit: Tales of Mischief, Mayhem and Guerrilla Warfare in the EU Referendum Campaign. London: Biteback Publishing.

Boomgaarden, Hajo, Schuck, Andreas, Elenbaas, Matthijs, and Claes De Vreese (2011). 'Mapping EU attitudes: Conceptual and empirical dimensions of Euroscepticism and EU support'. European Union Politics, 12:2, 241-266.

Bossetta, Michael (2017). 'Fighting fire with fire: Mainstream adoption of the populist political style in the 2014 Europe debates between Nick Clegg and Nigel Farage'. The British Journal of Politics and International Relations, 19:4, 715-734.

British Electoral Survey (2017). The Brexit election? The 2017 General Election in ten charts, available at: http://www.britishelectionstudy.com/bes-impact/the-brexitelection-the-2017-general-election-in-ten-charts/ (accessed 25 February 2019).

Butler, David, and Martin Westlake (2005). British Politics and European Elections 2004. Basingstoke: Palgrave.

Bynander, Fredrik, and Paul t' Hart (2006). 'When power changes hands: the political psychology of leadership succession in democracies'. Political Psychology, 27:5, 707730.

Caiani, Manuela, and Paolo Graziano (2016). 'Varieties of populism: insights from the Italian case’. Italian Political Science Review/Rivista Italiana di Scienza Politica, 46:2, 243 267.

Cowley, Philip, and Dennis Kavanagh (2016). The British general election of 2015. Basingstoke: Palgrave.

Crines, Andrew, and Tim Heppell (2017). 'Rhetorical style and issue emphasis within the conference speeches of UKIP's Nigel Farage 2010-2014'. British Politics, 12:2, 231249 .

Cutts, David, Goodwin, Matthew, and Caitlin Milazzo (2017). 'Defeat of the People's Army? The 2015 British general election and the UK Independence Party (UKIP)'. Electoral Studies, 48, 70-83.

Daniel, Mark (2005). Cranks and Gadflies: The story of UKIP. London: Timewell Press. 
Deacon, David, and Dominic Wring (2016). 'The UK Independence Party, populism and the British news media: Competition, collaboration or containment?'. European Journal of Communication, 31:2, 169-184.

De Vreese, Claes and Hajo Boomgaarden (2005). 'Projecting EU referendums: Fear of immigration and support for European integration'. European Union Politics, 6:1, 5982.

Dennison, James (2018). 'The Rug Pulled from Under Them: UKIP and the Greens'. Parliamentary Affairs, 71(suppl_1), 91-108.

Evans, Geoffrey and Anand Menon (2017) Brexit and British politics. Cambridge: Polity Press.

Farrell, Jason and Paul Goldsmith (2017). How To Lose A Referendum: The Definitive Story of Why The UK Voted for Brexit. London: Biteback Publishing.

Ford, Robert, and Matthew Goodwin (2014). Revolt on the right: Explaining support for the radical right in Britain. London: Routledge.

Gardner, Peter (2006) Hard Pounding: The Story of the UK Independence Party. Totnes: The June Press.

Gidron, Noam and Bart Bonikowski (2013). Varieties of Populism: Literature Review and Research Agenda. Working Paper Series, Weatherhead Center for International Affairs, Harvard University, No.13-0004.

Goodwin, Matthew (2007). 'The extreme right in Britain: still an 'ugly duckling' but for how long?'. The Political Quarterly, 78: 2, 241-250.

Gruber, Oliver, and Tim Bale (2014). 'And it's good night Vienna. How (not) to deal with the populist radical right: The Conservatives, UKIP and some lessons from the heartland'. British Politics, 9:3, 237-254.

Halikiopoulou, Daphne, and Sofia Vasilopoulou (2014). 'Support for the far right in the 2014 European parliament elections: a comparative perspective'. The Political Quarterly, $85: 3,285-288$.

Hayton, Richard (2010). 'Towards the Mainstream? UKIP and the 2009 Elections to the European Parliament'. Politics, 30:1, 26-35.

Heath, Oliver, and Matthew Goodwin (2017). 'The 2017 General Election, Brexit and the Return to Two-Party Politics: An Aggregate-Level Analysis of the Result'. The Political Quarterly, 88:3, 345-358.

Hernández, Enrique, and Hanspeter Kriesi (2016). 'The electoral consequences of the financial and economic crisis in Europe'. European Journal of Political Research, $55: 2,203-224$.

Hopmann, David, Elmelund-Præstekær, Christian, Albæk, Erik, Vliegenthart, Rens, and Claes de Vreese (2012). 'Party media agenda-setting: How parties influence election news coverage'. Party Politics, 18:2, 173-191.

Ipsos-Mori (2017). Issues index, available at: https://www.ipsos.com/ipsos-mori/enuk/issues-index-archive (accessed 25 February 2019). 
Ivarsflaten, Elisabeth (2008). 'What unites right-wing populists in Western Europe? Reexamining grievance mobilization models in seven successful cases'. Comparative Political Studies, 41:1, 3-23.

Jennings, Will, and Gerry Stoker (2017). 'Tilting towards the cosmopolitan axis? Political change in England and the 2017 general election'. The Political Quarterly, 88:3, 359369.

Kitschelt, Herbert (1986). 'Political opportunity structures and political protest: Anti-nuclear movements in four democracies'. British Journal of Political Science, 16:1, 57-85.

Lisi, Marco, Llamazares, Ivan and Myrto Tsakatika (2018). 'Economic crisis and party system change: The populist factor in Greece, Portugal and Spain'. West European Politics (this issue).

Mair, Peter (2013). Ruling the void: The hollowing of Western democracy. London: Verso Books.

McKibben, Ross (2017). 'In the shadow of the referendums'. The Political Quarterly, 88:3, 382-385.

Mellon, Jon, and Geoffrey Evans (2015). 'Class, Electoral Geography and the Future of UKIP: Labour's Secret Weapon?’. Parliamentary Affairs, 69:2, 492-498.

Mény, Yves, and Yves Surel (2002). 'The constitutive ambiguity of populism' in Yves Mény and Yves Surel (eds.) Democracies and the populist challenge. Basingstoke: Palgrave, $1-21$.

Mudde, Cas (ed.) (2017). The Populist Radical Right. London: Routledge.

Mudde, Cas and Cristóbal Rovira Kaltwasser (2013). 'Exclusionary vs. inclusionary populism: Comparing contemporary Europe and Latin America'. Government and Opposition, 48:2, 147-174.

Norris, Pippa (2003). 'Preaching to the converted? Pluralism, participation and party websites'. Party Politics, 9:1, 21-45.

Rooduijn, Matthijs, and Teun Pauwels (2011). 'Measuring populism: Comparing two methods of content analysis'. West European Politics, 34:6, 1272-1283.

Shipman, Tim (2016). All out war: The full story of how Brexit sank Britain's political class. London: HarperCollins UK.

Spiering, Menno (2004). 'British Euroscepticism'. European Studies: A Journal of European Culture, History and Politics, 20:1, 127-149.

Startin, Nicholas (2015). 'Have we reached a tipping point? The mainstreaming of Euroscepticism in the UK'. International Political Science Review, 36:3, 311-323.

Taggart, Paul (1995). 'New populist parties in Western Europe'. West European Politics, $18: 1,34-51$.

Taggart, Paul (2000). Populism. Birmingham, Open University Press.

Taggart, Paul (2018). 'Populism and euroscepticism: Understanding the link'. West European Politics (this issue). 
Tilley, James and Geoffrey Evans (2017). 'The New Politics of Class after the 2017 General Election'. The Political Quarterly, 88;4, 710-715.

Tournier-Sol, Karine (2015). 'Reworking the Eurosceptic and Conservative Traditions into a Populist Narrative: UKIP's Winning Formula?'. Journal of Common Market Studies, 53:1, 140-156.

UKIP (2017). Paul Nuttall announces a New Path for Britain: our direction of travel in key areas, UKIP press release, 21 February 2017, available at: http://www.ukip.org/new_path_guide_to_ukip_policy (accessed 9 April 2018).

Usherwood, Simon (2008). 'The dilemmas of a single-issue party-The UK Independence Party'. Representation, 44;3, 255-264.

Usherwood, Simon (2016). 'The UK Independence Party: The dimensions of mainstreaming' in Tijtske Akkerman, Sarah de Lange and Matthijs Rooduijn (eds.) (2016). Radical right-wing populist parties in Western Europe: into the mainstream?. London: Routledge, p.247-267.

Wallace, Mark (2014). The five tribes of UKIP, ConservativeHome, 10 December 2014, available at: https://www.conservativehome.com/highlights/2014/12/the-five-tribes-ofukip.html (accessed 25 February 2019).

Webb, Paul, and Tim Bale (2014). 'Why do Tories defect to UKIP? Conservative Party members and the temptations of the populist radical right'. Political Studies, 62:4, 961970.

Weyland, Kurt (2001). 'Clarifying a contested concept: Populism in the study of Latin American politics'. Comparative Politics, 34:1, 1-22.

YouGov (2016). Profiled for the first time: the UKIP membership, 22 October 2016, available at: https://yougov.co.uk/news/2016/10/22/introduction-ukip-partymembership/ (accessed 25 February 2019) 
Figures and Tables

Usherwood, S. Shooting the fox? UKIP's populism in the post-Brexit era. West European Politics 
Figure 1: UKIP press releases, by content.

Source: Usherwood. Forthcoming

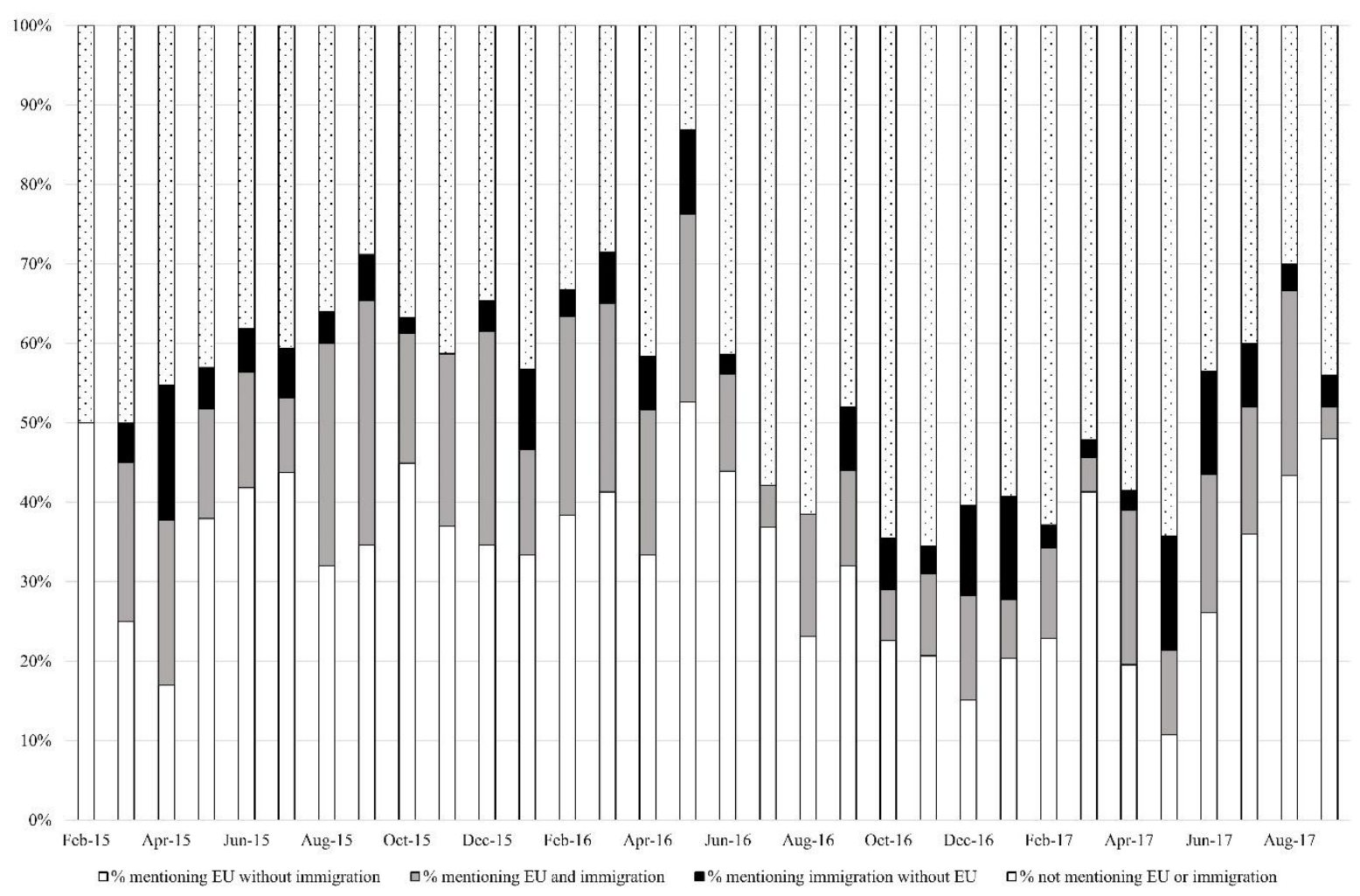


Figure 1: Express articles mentioning UKIP, by content.

Source: Usherwood, forthcoming.

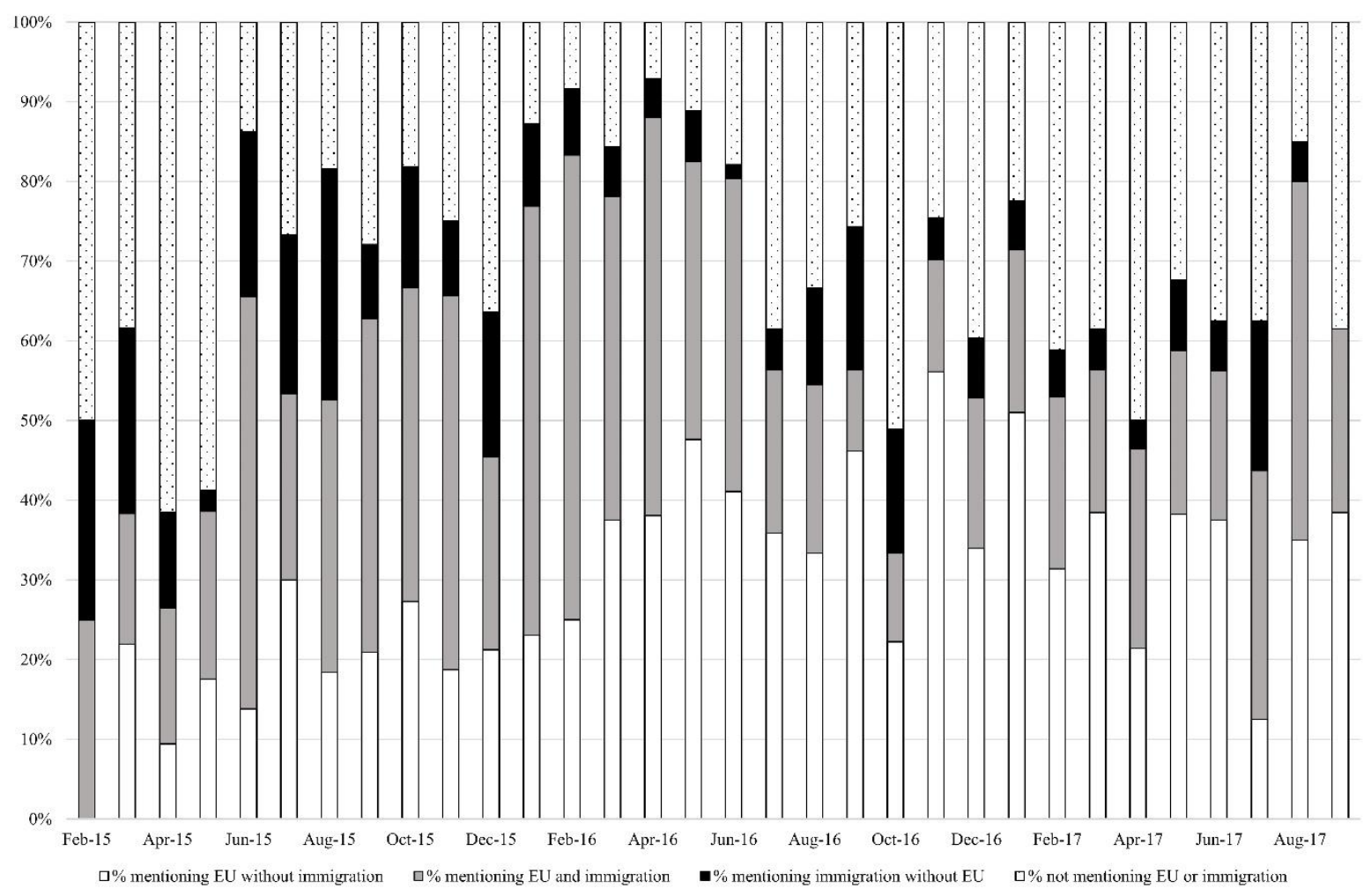


Figure 3: UKIP press releases \& Express articles, by mention to party leader or Nigel Farage.

Source: Usherwood, forthcoming.

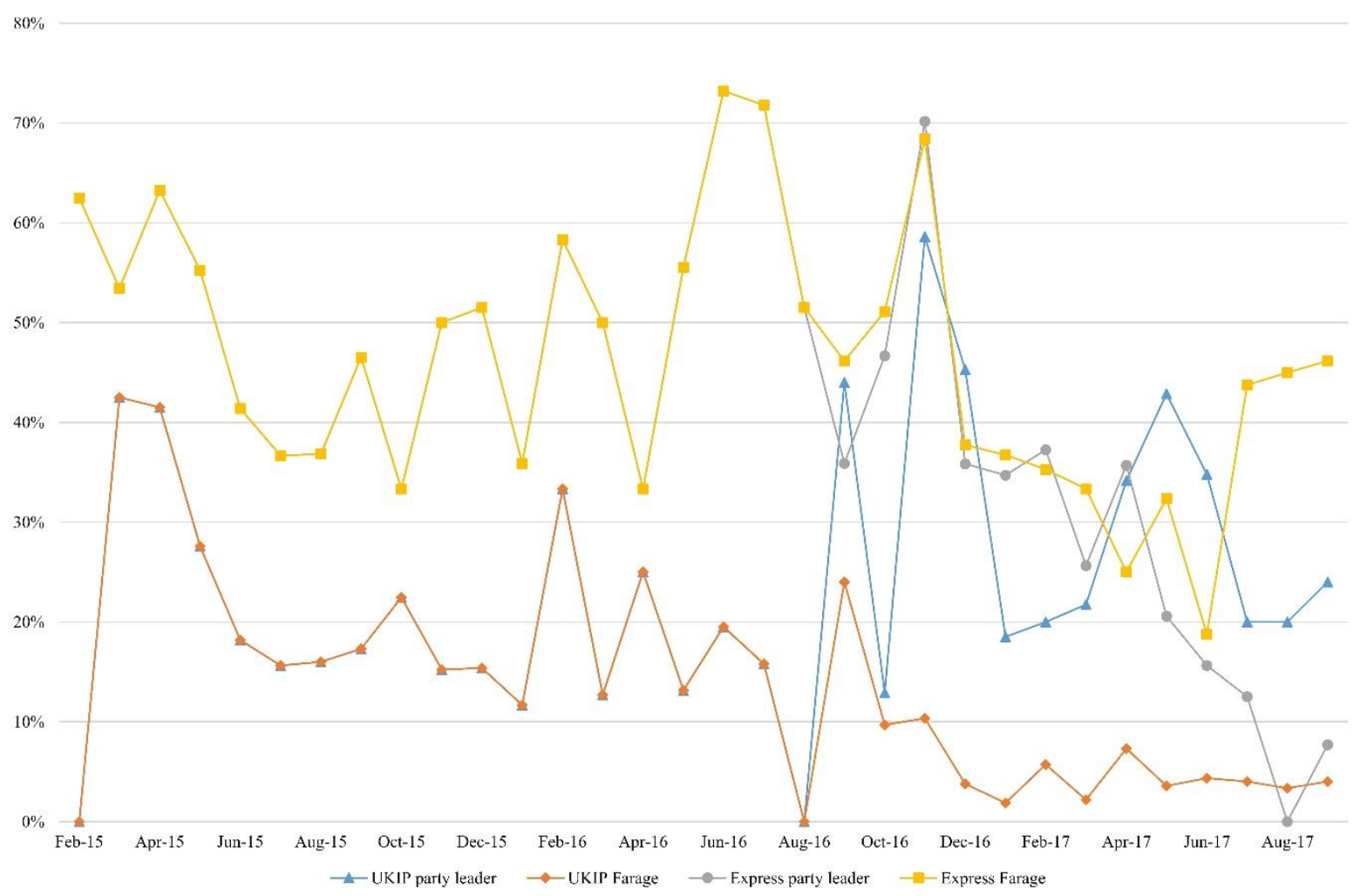


Figure 4: UKIP press releases \& Express articles, by mention of Labour or Conservatives.

Source: Usherwood, forthcoming.

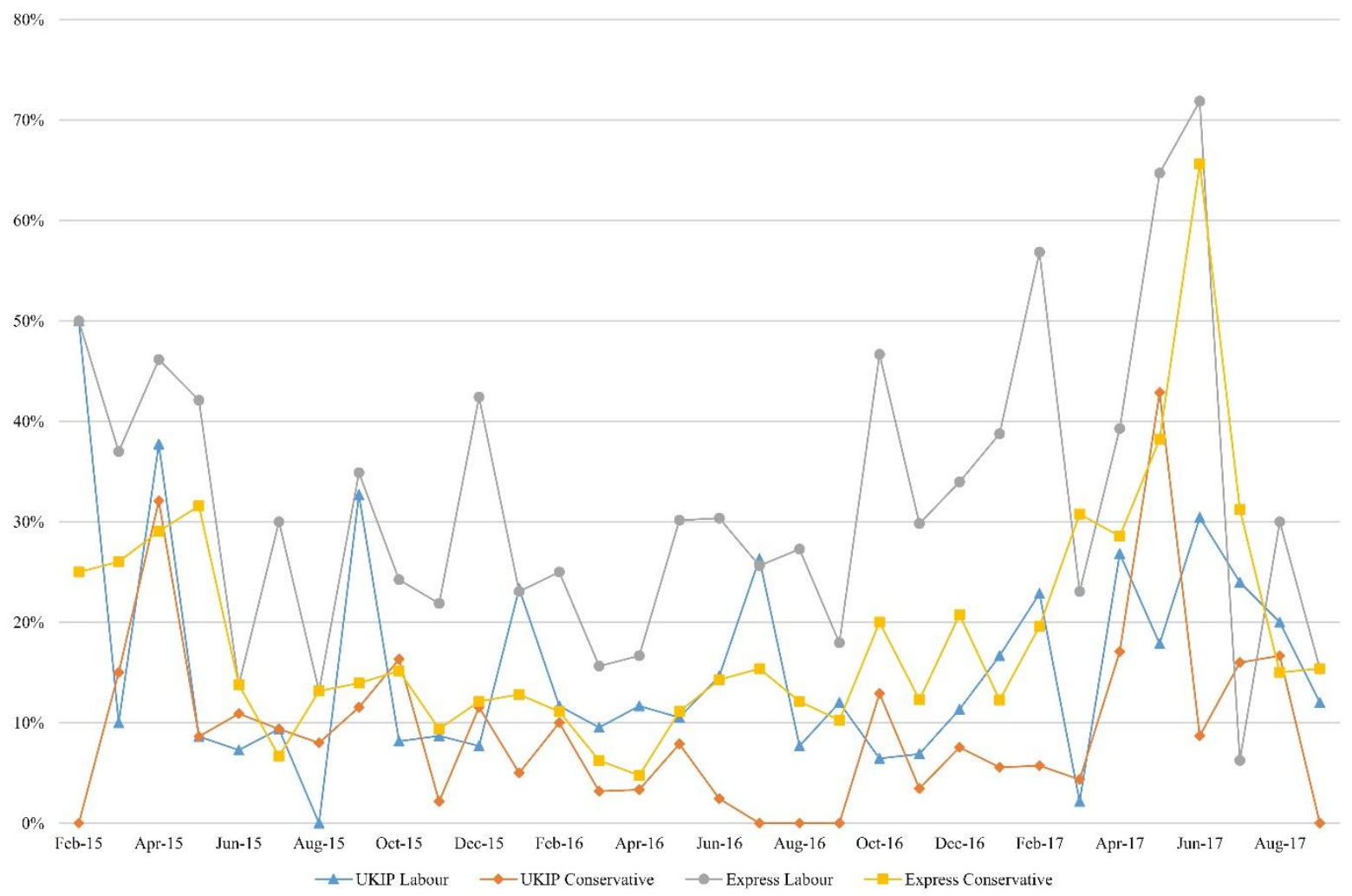


Figure 5: UK opinion polling, by vote intention (\%).

Source: ukpollingreport.co.uk

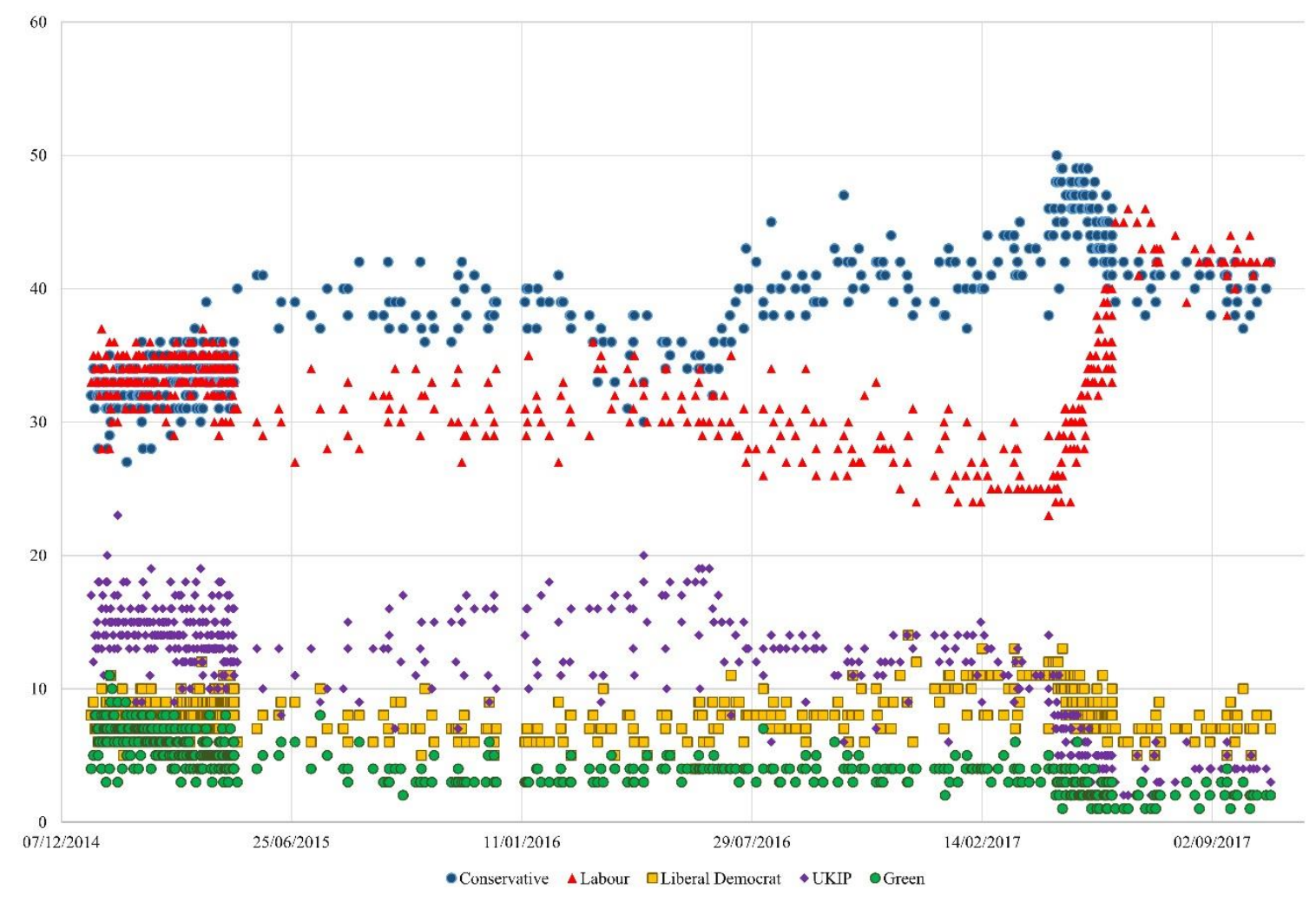


Figure 6: Intention to vote UKIP versus importance of select issues (\%).

Sources: ukpollingreport.co.uk, Ipsos Mori.

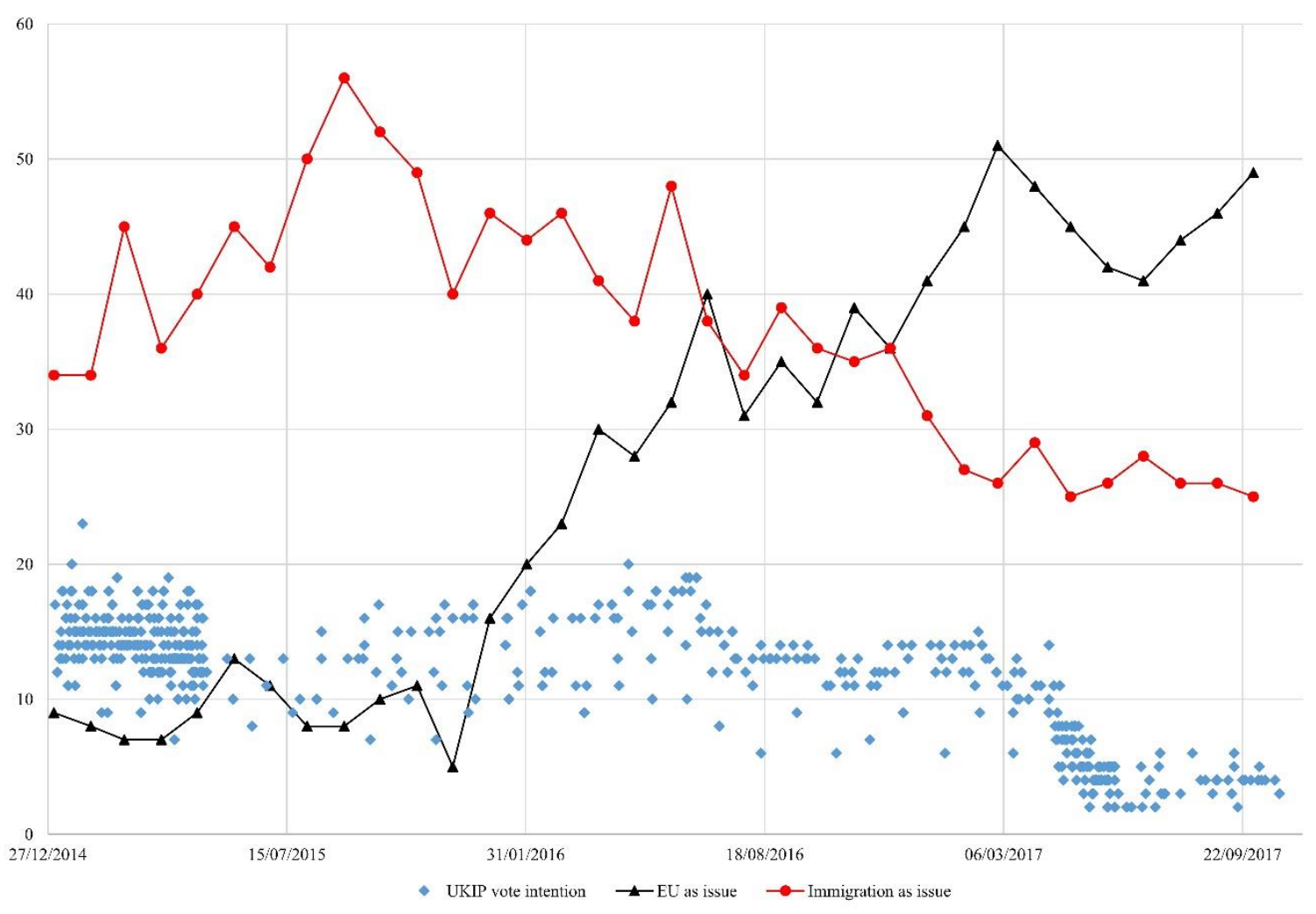


Table 1: Frequency of subject mentions, UKIP press releases and Express articles mentioning UKIP

Sources: Usherwood, forthcoming www.ukip.org, Nexis database.

\begin{tabular}{|c|c|c|c|c|c|c|c|c|}
\hline & \multirow{2}{*}{\multicolumn{2}{|c|}{$\begin{array}{c}27 / 2 / 15- \\
07 / 05 / 2015\end{array}$}} & \multirow{2}{*}{\multicolumn{2}{|c|}{$\begin{array}{l}08 / 05 / 2015- \\
23 / 06 / 2016\end{array}$}} & \multirow{2}{*}{\multicolumn{2}{|c|}{$\begin{array}{l}\text { 24/06/2016- } \\
08 / 06 / 2017\end{array}$}} & \multirow{2}{*}{\multicolumn{2}{|c|}{$\begin{array}{l}\text { 09/06/2017- } \\
25 / 09 / 2017\end{array}$}} \\
\hline & & & & & & & & \\
\hline & UKIP & Express & UKIP & Express & UKIP & Express & UKIP & Express \\
\hline$N$ & 107 & 226 & 632 & 575 & 384 & 494 & 96 & 71 \\
\hline N/week & 10.7 & 22.6 & 10.7 & 9.7 & 7.7 & 9.9 & 6.2 & 4.6 \\
\hline \multicolumn{9}{|l|}{$\underline{\text { Subject }}$} \\
\hline $\begin{array}{l}\text { EU without } \\
\text { Immigration }\end{array}$ & $21.50 \%$ & $13.72 \%$ & $39.40 \%$ & $27.65 \%$ & $23.18 \%$ & $37.85 \%$ & $41.67 \%$ & $33.80 \%$ \\
\hline $\begin{array}{c}\text { EU \& } \\
\text { Immigration }\end{array}$ & $17.76 \%$ & $17.70 \%$ & $20.57 \%$ & $38.43 \%$ & $10.16 \%$ & $18.83 \%$ & $16.67 \%$ & $28.17 \%$ \\
\hline $\begin{array}{c}\text { Immigration } \\
\text { without EU }\end{array}$ & $10.28 \%$ & $15.04 \%$ & $5.54 \%$ & $10.26 \%$ & $7.03 \%$ & $8.30 \%$ & $5.21 \%$ & $5.63 \%$ \\
\hline $\begin{array}{c}\text { Neither EU } \\
\text { or } \\
\text { Immigration }\end{array}$ & $50.47 \%$ & $53.54 \%$ & $34.49 \%$ & $23.65 \%$ & $59.64 \%$ & $35.02 \%$ & $36.46 \%$ & $32.39 \%$ \\
\hline party leader & $40.19 \%$ & $59.73 \%$ & $19.30 \%$ & $47.65 \%$ & $30.21 \%$ & $44.13 \%$ & $30.21 \%$ & $8.45 \%$ \\
\hline Nigel Farage & $40.19 \%$ & $59.73 \%$ & $19.30 \%$ & $47.65 \%$ & $7.03 \%$ & $46.15 \%$ & $3.13 \%$ & $36.62 \%$ \\
\hline Labour & $23.36 \%$ & $43.81 \%$ & $12.34 \%$ & $27.30 \%$ & $14.84 \%$ & $37.45 \%$ & $18.75 \%$ & $33.80 \%$ \\
\hline Conservatives & $21.50 \%$ & $28.76 \%$ & $9.38 \%$ & $13.91 \%$ & $9.38 \%$ & $20.24 \%$ & $10.42 \%$ & $33.80 \%$ \\
\hline
\end{tabular}

